\title{
INSTITUTE NOTES
}

The Annual General Meeting, which was postponed indefinitely in July,

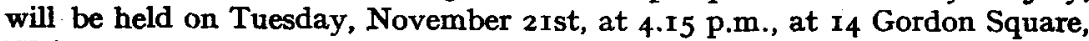
W.C.I. On this occasion it will be a formal meeting only.

\section{OBJECTS OF THE INSTITUTE}

The British Institute of Philosophy exists to bring leading exponents of various branches of Philosophy into direct contact with the general public, with the purpose of satisfying a need felt by many men and women in every walk of life for greater clearness and comprehensiveness of vision in human affairs.

With this broad educational purpose in view, the Institute-

(r) Provides at suitable times in the day and evening courses of lectures by leading exponents in the more important subjects coming within the scope of Philosophy. All branches of Philosophy are represented -Ethics and Social Philosophy, the Philosophy of Law and of the Sciences, of the Fine Arts and of Religion, as well as Logic and Metaphysics and Psychology.

These lectures are free to members.

(2) Issues a quarterly philosophical journal (free to members).

(3) Proposes to form a philosophical Library.

(4) Gives guidance and assistance to individuals in their philosophical reading.

(5) Encourages research in Philosophy.

There are Local Centres of the Institute at Bangor, Cardiff, Liverpool, Manchester, Newcastle and Durham, and Sheffeld.

Further information and forms of application for membership may be had on application to the Director of Studies, at University Hall, 14 Gordon Square, London, W.C.1.

\section{[Suggested] \\ FORM OF BEQUEST}

I bequeath to THE BRITISH INSTITUTE OF PHILOSOPHY the sum of $\ldots \ldots \ldots \ldots \ldots \ldots \ldots$ free of duty, to be applied to the purposes of that Institute, and I declare that the receipt of the Honorary Secretary, or other proper officer for the time being of that Institute, shall be sufficient discharge for the same.

THE PLAIN VIEW, published quarterly by The Ethical Union, does not (probably) express the plain man's views; but it is written for the plain man, and expresses views on the civilization of a mass democracy, a civilization which the writers of THE PLAIN VIEW wish to see integrated, humanized, and sustained by men and women sensitive to established values, fertilized by the achievements of the past, and equal to present opportunities and needs.

The current issue, in addition to editorials and book reviews, has articles by Professor Laird, John Katz, and Ursula Edgcumbe. Price 7d. (2/4 p.a.) post free from The Ethical Union, 41/42, Chandos House, Buckingham Gate, S.W.1. 